\title{
O RESGATE DE UM ESQUECIMENTO - A COLÔNIA DE LEOPOLDINA*
}

\author{
LuCelinda Schramm Correa \\ Universidade Federal Fluminense
}

Diversos foram os empreendimentos coloniais implementados na região ao de sul Salvador, Capitania da Bahia, ao longo do século XIX. Entretanto, dentre as diversas colônias estrangeiras instaladas na região, apenas uma destaca-se, seja pela sua permanência, seja pelo «sucesso» do empreendimento. Esta é Colônia Leopoldina, situada às margens do rio Peruípe, na Vila Viçosa ${ }^{1}$, Comarca de Caravelas, Capitania da Bahia.

Neste artigo pretendemos fazer uma retrospectiva da Colônia Leopoldina começando pela sua fundação e alguns dos seus primeiros proprietários. Também não poderemos deixar de mencionar a Colônia Frankental, ou Fazenda Jacarandá, devido às suas implicações, como demonstra a documentação levantada, no desenrolar dos fatos que se sucederam entre os anos de 1823 e 1832, aos quais denominamos de conflitos entre os habitantes da Vila Viçosa e os colonos alemães e suíços.

\section{DA FUNDAÇÃO DA COLÔNIA}

A fundação da colônia situa-se em algum momento entre os anos de 1818 e 1819 sendo, portanto, anterior à de Nova Friburgo instalada no Rio de Janeiro. Há divergências no tocante à data exata de sua fundação, pois pelos documentos inéditos levantados e pelos dados provenientes das fontes primárias e fontes secundárias, as datas da fundação variam entre 1816 e 1819 . Von Martius diz-nos, de forma indireta, que o estabelecimento da colônia é anterior a 1818, pois quando de sua passagem por Ilhéus

\footnotetext{
*Este artigo é uma reelaboração do quarto capítulo da tese de Doutorado intitulada «A torturante ausência de uma presença: A imigração alemã na Bahia do século XIX» (São Paulo, USP, 2003). 1. $\mathrm{Na}$ atualidade corresponde ao município de Nova Viçosa/BA.
} 
relata a presença de Peter Weyll ${ }^{2}$ que teria sido um dos formadores da colônia, e depois se deslocado para o Almada. Haldemann (1931), Edelweiss (1974), Carneiro (1950), Fouquet (1974) e Braz do Amaral (1923), entre outros, dão como data da fundação 1818, já Rouve (1922) fala em 1819.

Cremos, entretanto, baseados numa memória da colônia escrita pelo Cônsul Tavel da Confederação Helvética no Rio de Janeiro ${ }^{3}$, que podemos afirmar, com quase total certeza, que o seu estabelecimento tenha se dado em 1819 , tendo em vista que ao final de 1818 foi autorizado pelo Ouvidor da comarca de Vila Viçosa o estabelecimento dos colonos, os quais solicitaram um Alvará à D. Pedro, à época regente do trono. Deste Alvará não temos cópia, mas o mesmo documento ${ }^{4}$ menciona um Ofício de 25 de Junho de 1819 do Conde de Palmas ao Ouvidor de Porto Seguro que dá a conhecer das intenções de Sua Majestade com relação aos colonos. Por sua vez, o Ouvidor, por Ofício de 15 de Julho, informa às autoridades de Viçosa, que tomam conhecimento do mesmo em 31 de Julho de 1819.

Outro documento ${ }^{5}$, datado de 08 de Junho de 1819 , trata do pedido dos colonos de dar o nome da esposa do Príncipe Regente, D. Leopoldina, à Colônia, bem como contém uma cópia do ofício recebido do Ouvidor da comarca de Porto Seguro, datado de 15 de outubro de 1819, que manda a Câmara de Vila Viçosa demarcar as terras dos colonos alemães que se achão no rio acima da mesma villa como também prestar-lhes todo o necessário que for a bem do aumento dos mesmos pagando elles com séo dinheiro (...). Cópia da Decisão No 19-Marinha ${ }^{6}$ de 8 de Junho de 1819 da parte do Conde dos Arcos ao Governador e Capitão General da Capitania da Bahia, o ofício datado de 08 de junho enviado pelo Conde de Palmas, Governador e Capitão Geral da Capitania da Bahia, permite que a colônia possa ser denominada Leopoldina em ho-

\footnotetext{
2. Segundo Steger, von Martius quando esteve em Ilhéus em 1817 foi hospedado por Peter Wegl (Weyll), de Francfort, e Friedrich Schimid, de Stuttgart, em Almada (Ilhéus). in STEGER, HannsAlbert. As relações econômicas teuto-brasileiras no período de 1815 a 1830. In FREYRE (Org.), 1974: p. 449.

${ }^{3}$ A.N. IA6-154-Fundo Agricultura, doc. 1 .

${ }^{4}$ Idem.

${ }^{5}$ A.N. IA6-154-Fundo Agricultura, doc. 5.

${ }^{6}$ Catálogo das cartas régias, provisões, alvarás, avisos, portarias, etc., expedidas ao governador e mais tarde Vice-Rei do Rio de Janeiro de 1662 a 1821.

Erário Régio de oito do corrente mês expedido pela'Secretaria do Estado dos Negócios Estrangeiros e da Guerra vem participar que tendo S.M.Fidelíssima El'Rei Nosso Senhor sido infformado de se haver fundado com a melhor perspectivas o estabelecimento Rural da Colônia Allemã no sítio das margens do Peruíbe no districto de Villa Viçosa a cuja testa se haxa o industrioso emprehendedor Freyress não podia S.M. deixar de manifestar neste objecto a maior satisffação e que condescendendo agora com os desejos e solicitações daquelle Estabelecimento tomasse o nome de Leopoldina mandandosse (...) promover os trabalhos de tais collonos em confformidade pois desta real Ordem (...) Bahia. Vinte e cinco de junho de mil oito centos e dezenove - Ass. Conde de Palmas.
} 
menagem a esposa de D. Pedro e manda atender as solicitações dos colonos de forma a contribuir para o sucesso do empreendimento.

Pelo que consta nas memórias escritas pelo Cônsul Tavel ${ }^{7}$ os fundadores da Colônia Leopoldina receberam duas sesmarias de uma légua de terras em quadra situadas a margem do rio Peruípe em Vila Viçosa, ou nas palavras de Tavel quatro léguas em quadro coletivamente. Isto significa que as sesmarias foram concedidas de forma coletiva aos colonos alemães e suíços. Por este documento Pedro Paycke, Georg Freyreiss, e o Barão von Bunche seriam os possuidores de uma das sesmarias, e Borrel, Beguin e Hulguemin os da outra. Neste ponto começamos a encontrar divergências entre os relatos e os documentos levantados.

Handelmann (1931, p.457) dá como fundadores da colônia Busch, Peycke ${ }^{8} \mathrm{e}$ Freyreiss. Já Edelweiss (1974, p. 595), ao utilizar-se de dados fornecidos por Manu Neeser ${ }^{9}$, diz-nos que, em 1818 foi fundada, na província brasileira da Bahia, a Colônia Leopoldina, pelo cônsul Pedro Peycke, os naturalistas Freyreiss e Morhardt, naturais de Francoforte do Meno, aos quais, pouco depois, se juntaram os suíços Abraão Langhans e David Pache. Observamos que o autor não cita o ex-oficial e engenheiro holandês Guilherme Frederico de Bussche (Busch), que foi dos primeiros que para ali se transferiram e anos após prestou à Bahia relevantes serviços, e que, segundo Tölsner, logo não tardou que se lhe se juntassem outros (Edelweiss, p.595).

A documentação pertinente existente no Arquivo Nacional nos permite ter uma melhor clareza quanto os fundadores da Colônia. Pelas cópias dos Autos de Medição e de Marcação ${ }^{10}$ temos a exata localização das terras doadas e o nome dos seus proprietários.

${ }^{7}$ A.N. IA6-154-Fundo Agricultura, doc. 1.

${ }^{8}$ TÜTKEN,1986, à p. 26 refere-se Peycke da seguinte forma: (...) como figura de certa importância para este período temos o hamburguês Peter Peycke, aqui estabelecido com uma firma de exportação. Quando, em 1820, foi aberto no Brasil o primeiro consulado alemão, Peycke foi nomeado cônsul, cargo que ocupou até 1836 , ano de sua morte em uma fazenda de sua propriedade no interior da Bahia

${ }^{9}$ Não faz maiores referências sobre o autor, dizendo apenas que ele por longos anos, se dedicou a pesquisas em torno às colônias do Peruíbe [grafia do original]. Ibidem.

${ }^{10} \mathrm{~A}$ N. Fundo Agricultura. IA6, no b: Certifico que revendo o Arquivo da mesma Câmara encontrei o Auto dessas terras e de marcação que pede o suplicante: Auto de Medição e de Marcassão de uma légua de terras no lugar da nova povoação Leopoldina da parte Sul do Rio Geral, nesta Villa denominado Peruípe no lugar chamado Pombal concedidas por graça de sua Magestade aos colonos Suissos Carlos Luiz Borrel, Felippe Huguenin e Pedro Henrique Beguin. Escrivão Antonio Pereira dos remédios - Anno de Nascimento de Nosso Senhor Jesus Christo de mil oitocentos e vinte e hum aos vinte dias do mês de (...), e o IA6, no c: Certifico que revendo o Arquivo da mesma Câmara encontrei o Auto dessas terras e de marcação que pede o suplicante: Auto de Medição e de Marcassão de uma légua de terras no lugar da nova povoação Leopoldina da parte Sul do Rio Geral, nesta Villa denominado Peruípe no lugar chamado Riacho do Ouro, concedidas por graça de sua Magestade aos Colonos Suissos A. Languin e David Pache. Escrivão Antonio Pereira dos remédios - Anno de Nascimento de Nosso Senhor Jesus Christo de mil oitocentos e vinte e hum aos Dezessete dias do mês de dezembro do dito anno, e (...) 
Podemos notar que os documentos citados não fazem menção a alguns dos nomeados pelo Cônsul Tavel como fundadores da Colônia - Georg Freyress, Pedro Paycke e Barão von Bunche. Qual documento devemos considerar, uma memória escrita em 1832, ou a cópia dos autos de medição e demarcação feita em 1821, portanto mais próximo da época da fundação da Colônia?

Uma outra questão também deve ser levantada. Um outro sesmeiro não consta nos documentos supracitados, entretanto, foi ele possuidor de duas datas de terras na referida área. Estamos nos referindo ao alemão João Martinho Flack (ou Flach). Nos documentos das sesmarias ele aprece em um dos documentos como único beneficiário da doação das terras, e noutro junto a outros alemães. No primeiro caso, é possuidor de meia légua de terras em quadro no districto de Caravellas acima da Villa Viçosa na vizinhança da Colônia Leopoldina por portaria de 21 de Janeiro de 1823, do que se deo posse ao Supplicante em Dezembro de $1824(. . .)^{11}$. Este documento refere-se ao sítio Helvécia. No segundo ${ }^{12}$, aparece como um dos beneficiários da doação de meia légua de terras em quadro juntamente com Carlos Luiz Borrel, Felipe Hugermin, Pedro Henrique Béguin, Abran Langhaens e David Pache. Também é citado no documento Georg Anton Freyreiss.

No tocante as terras doadas a Carlos Luiz Borrel, Felipe Hugermin, Pedro Henrique Béguin, Abran Langhaens e David Pache estas compõem a Colônia Leopoldina, pois quando da demarcação e marcação do sítio Helvécia há a referência de que as terras pertencentes à Colônia Leopoldina fariam divisas com as ditas terras. Entretanto, a leitura do conjunto dos documentos nos dá a entender que a Colônia Leopoldina englobaria o conjunto das terras das duas sesmarias, pois apenas na documentação das sesmarias as terras aparecem separadas.

Por outro lado, como podemos perceber, mesmo utilizando fontes indiscutíveis como os documentos em tela, os beneficiários da doação das sesmarias variam de acordo com a fonte utilizada mantendo-se, portanto, uma discrepância quanto aos reais proprietários e fundadores da colônia.

No tocante a estes personagens pouco podemos esclarecer baseados nos dados levantados, mas tentaremos fazer uma descrição, embora muito pouca precisa, de dois dos personagens principais na constituição da colônia, João Martinho Flach e Georg Anton Freireyss.

O primeiro é suíço natural de Schffhausen, nascido em 1781. Consta no Registro de Estrangeiros ${ }^{13}$, onde também encontramos seu nome grafado como João Martinho Flack ou Flak, que quando de sua chegada ao Rio de Janeiro, aos 28 anos, em maio de 1809, procedente de Falmouth declarou-se solteiro, negociante de fazendas, e passou a residir

\footnotetext{
${ }^{11}$ A N. Sesmarias. COD. BI2.146. Datas Limites 1822-1827.

${ }^{12}$ A N. Sesmarias. COD. BI2.148. Datas Limites 1824-1828.

${ }^{13}$ Registro de Estrangeiros. 1808-1822, 1960, p. 14-15.
} 
defronte a Ribeira. Veio acompanhado por um sócio de nome Carlos Meyer, originário de Stuttgart, de estatura ordinária, rosto redondo, bastante barba, olhos azuis ${ }^{14}$.

Ainda de acordo com o Registro de Estrangeiros, em maio de 1819, parte para a Suíça, retornando de sua terra natal no ano seguinte, chegando ao Rio de Janeiro em 18 de agosto de 1820 quando vai para Cantagalo e ali permanece por dois meses. Em maio de 1821 partem, juntamente com Felipe Stenning ${ }^{15}$, Jorge Antonio Schäffer e mais um criado ${ }^{16}$ para Campos, por Macaé. Consta que D. Pedro teria sido oferecido a Schäffer uma sesmaria de sua livre escolha. Ao que parece, as terras de Campos não foram do seu agrado, partindo então para a Bahia, onde se estabeleceu às margens do rio Peruípe próximo a Colônia Leopoldina, e Flach recebeu em doação duas datas de meia légua em quadra na mesma localidade, como dito anteriormente.

Ainda de acordo com o Registro de Imigrantes ${ }^{17}$, temos notícia que Flach seguiu para a Bahia em 31 de março de 1828, fazendo ainda outra duas viagens (1829 e 1830) com destino a Caravelas. O último registro referente a Martinho Flach data de 1839, quando de sua chegada ao Rio de Janeiro, onde possuía uma chácara no Engenho Novo ${ }^{18}$. Em geral, ele viajava em companhia de escravos ou libertos, como está descrito no Registro de Estrangeiros. Podemos afirmar, com certeza, que sua morte ocorreu em 1868, pois assim está escrito na lápide do seu túmulo ${ }^{19}$.

Freireyss, filho de um sapateiro, nasceu em Frankfurt em 12 de julho de 1789, vindo a morrer no Brasil em sua colônia à $1^{\circ}$ de abril de 1825. A data de sua chegada ao Brasil ainda não está clara, mas com certeza antecede ao ano de 1817, pois acompanhou Langsdorff ao Brasil, no período de 1814 a 1815, assim como ao barão de Eschevege numa viagem a província de Minas Gerais (1814), ao final da qual enviou ao consulado sueco um relatório contendo suas observações sobre mineralogia, zoologia, botânica e aspectos sociais. Entrou para o serviço do governo real e, entre 18151817, acompanhou, parcialmente, o príncipe Maximiliano de Wied-Neuwid em suas viagens pelas províncias do Rio de Janeiro, Espírito Santo e Bahia explorando o vale do rio Mucuri. Creio que foi neste período, que percebendo as potencialidades da região do vale do Mucuri, intentou instalar uma colônia de agricultores ${ }^{20}$ na região. Esta

\footnotetext{
${ }^{14}$ Idem.

${ }^{15}$ Alemão, com 41. Apud Registro de Estrangeiro

${ }^{16} \mathrm{O}$ congo fôrro Alberto, de 22 anos. Idem.

${ }^{17}$ Registro de Estrangeiros. 1823-1830, 1961, p. VII.

${ }^{18}$ Também encontramos referência a João Flach, filho de Martinho Flach, nascido no Brasil em 1818, que segue para a Suíça aos 15 anos, aparentemente para estudar, retornando aos 21 anos, quando é descrito como tendo estatura regular, cor branca, cabelos castanhos, olhos pardos, rosto comprido e pouca barba. Registro de Estrangeiros. 1831-1839,1962. p. XIII

${ }^{19}$ Pouco após a foto ser tirada todas as lápides do antigo cemitério foram roubadas segundo nos foi informado pela Dra. Jean Albuquerque, médica e moradora de Nova Viçosa que se interessa pelo estudo da antiga Colônia e dos seus colonos.

${ }^{20}$ Quando de sua fundação a colônia e sua área pertencia ao termo de Caravelas, hoje município.
} 
oferecia uma série de vantagens, tais como a proximidade com o porto de Caravelas, a interligação por canais entre o rio Mucuri e o Peruípe, e a qualidade do solo, um dos melhores $^{21}$, além de já existirem cafezais em Vila Viçosa, localizada entre a Vila de Mucuri e a de Caravelas Após sua instalação passou a se dedicar aos estudos de emigração, publicando em 1824 um volume sobre a colônia Leopoldina que ofertou ao ministro José Bonifácio de Andrade e Silva. A ausência de mais registros deixa uma lacuna a ser preenchida sobre esta personagem.

\section{A COLÔNIA LEOPOLDINA E SUA EVOLUÇÃO}

A Colônia Leopoldina era formada por três fazendas: Riacho d'Ouro, Pombal e Helvécia, cujos proprietários já mencionamos. Além deles outros imigrantes, alemães e suíços, residiam e trabalhavam nas terras da colônia, embora não fossem proprietários de terras. Dentre alguns deles podemos citar $\mathrm{Maulaz}^{22}$, que em carta de 9 de janeiro de $1833^{23}$, louva as qualidades das terras do Espírito Santo, sua fertilidade, proximidade com o porto, a navegabilidade do rio Itapemirim, salubridade do clima, e ausência de «índios antropófagos», sugerindo a vinda de pessoas industriosas (habitants industrieux) para a formação de uma colônia de trabalhadores, e que na «la rivière d'Itapemirim» já existem «50 milles piêdes» de café ${ }^{24}$.

Se Edelwisse (1974: p595) considera a Colônia de Leopoldina a primeira colônia agrícola fundada por alemães, também Rouve (1928: p. 693) indica que a sua fundação é anterior a Colônia de Nova Friburgo, no Morro Queimado. Já Carneiro (1950: p. $1015)^{25}$ a considera uma «pequena» colônia que não se desenvolveu bem. Para Viotti (1999: p. 308), a Colônia de Leopoldina em 1848 exportava 70 mil arrobas de café, contando com 130 pessoas livres entre estrangeiros e nacionais, e mais de 1.000 escravos. Mattoso (1978: p. 92) nos diz que a fundação da colônia data de 1818 e que a sua produção de café passou de 6.610 sacos de sessenta quilos em 1836 para 24.384 sacos em 1853. O Relatório Provincial-Bahia- $1842^{26}$, quando se refere às terras das Comarcas de Caravelas e Porto Seguro, refere-se a elas como quase totalmente despovoadas e

\footnotetext{
${ }^{21}$ Apesar do predomínio dos latossolos há uma grande mancha de podzol na foz dos rios Itanhém e Jucuruçu. Ao longo dos rios rio Colônia (Almada), Mucuri, Caravelas e Peruíbe predomina o solo podzólico. Já junto próximo ao litoral, o rio Jequitinhonha apresenta uma mancha de solo glay e podzol.

${ }^{22}$ Não sabemos qual dos Maulaz foi o autor da cartà, pois no

Registro de Estrangeiros. 1808-1822

encontramos 4 (quatro) imigrantes com este sobrenome.

${ }^{23}$ Não consta o nome do destinatário.

${ }^{24}$ A. N. Série Agricultura. IA6-159. S/D- 1825-1833. 25 doc.

${ }^{25}$ Diz que não se desenvolvera bem a colônia de Santa Leopoldina (sic), na Bahia, fundada em 1818 pelos empresários Busch, Peycke e Freyress.

${ }^{26}$ Relatório Provincial-Bahia-1842. p. 9.
} 
incultas, sendo que a Colônia de Leopoldina é a única que existe, composta pela maior parte de suissos, e allemães, exportando em 1836 vinte mil arrobas de café, exporta hoje para mais de 36 mil (...), entretanto, o Relatório Presidencial-1861 ${ }^{27}$ informa que a colônia não mais existe, pois todos os antigos colonos tornaram-se proprietários de fazendas, tendo inclusive mudado a denominação da associação de fazendeiros passando de Colônia Leopoldina para Sociedade do Porto de São José (LYRA, 1997: p. 22-23) ${ }^{28}$. Além dos já mencionados, outros autores, Fouquet (1974: p. 57) ${ }^{29}$, Palazzolo (1973:

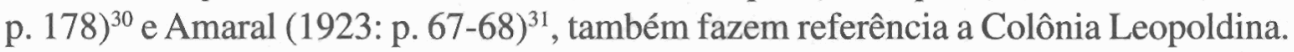
Neste ponto retomamos as palavras do Cônsul Tavel, que ao descrever a situação da colônia em 1832 diz que a extensão da colônia é de uma légua de frente sobre a direita de flanco de uma légua sobre a esquerda, composta de grandes plantações, povoada por 86 brancos e 489 escravos, e composta por mulheres e crianças $^{32}$, tendo produzido no ano de 183120 mil arrobas de café. Como podemos observar, há um aumento significativo tanto do número de brancos (colonos) como no dos escravos, sendo este muito mais expressivo.

Tendo em vista direcionamento da agricultura da colônia para a produção de café, fato já mencionado, a presença de um alto número de escravos não causa espanto, e se observamos o gráfico $n^{\circ} 1$, podemos ver que há um significativo aumento da entrada de escravos na Bahia como um todo no período 1816-1850, mas que o aporte de escravos ao sul da província foi ainda mais significativo, sugerindo uma forte expansão das

\footnotetext{
${ }^{27}$ Relatório Provincial-Bahia-1861. Falla da Presidência. p 35.

${ }^{28}$ Cópias das atas de reunião dos fazendeiros.

${ }^{29} \mathrm{~A}$ "Colônia Leopoldina" -como era conhecida em 1825- situava-se no extremo sul da Bahia, às margens do rio Peruípe ou rio Caravelas, constituída por um grupo de empresários fazendeiros, dentre os quais o mais conhecido foi o naturalista Jorge Guilherme Freyreiss. Segundo Tschudi, era a colônia formada por 40 fazendas, cujos proprietários eram vinte brancos, alem de alemães $e$ suíços, também alguns franceses e belgas. Mantinham, ao todo, 2.000 escravos e plantavam principalmente café, conhecido então como café de Caravelas.

${ }^{30} \mathrm{Com}$ fundamento nessa lei [25 de maio de 1808], alguns alemães adquiriram terras. Em 1818 foram concedidas diversas sesmarias no Peruípe, perto de Viçosa, no sul da Bahia, ao naturalista Jorge Guilherme Freyress e companheiros. Com outros imigrantes fundaram a primeira colônia agrícola alemã, à qual deram o nome Leopoldínia ou Leopoldina em homenagem à então princesa real. Tornou-se ela, no entanto, dentro em breve, numa colonia de fazendeiros que se baseavam na escravatura e onde se plantava o café.

${ }^{31}($...) Por isto foi, em 1818, fundada a colônia «Leopoldina", no município de Villa Viçosa, á margem do rio Peruhype, sem que se possa saber com exactidão quantos colonos extrangeiros entraram ali, podendo-se, affirmar que 1851 era florescente seu estado. O typo de colônia tinha porém desapparecido, porque o trabalho agrícola era todo feito por escravos. Os europeus eram donos das fazendas, administradores e empregados de graduação. Havia ali 43 fazendas de café que pertenciam a alguns brasileiros, suissos, prussianos, hanoverianos, etc., com 650 pessoas de família, 25 homens livres empregados e 1.245 escravos. A colônia "Leopoldina» chegou a exportar 100 mil arrobas de café e os escravos chegaram mais tarde a 2.000.

${ }^{32}$ Tradução do original em francês. A.N. IA6-154. Fundo Agricultura, doc. 1.
} 


\section{Gráfico 1 - Estimativas de desembarque de africanos na Bahia por quinquênio}

(1781-1855)

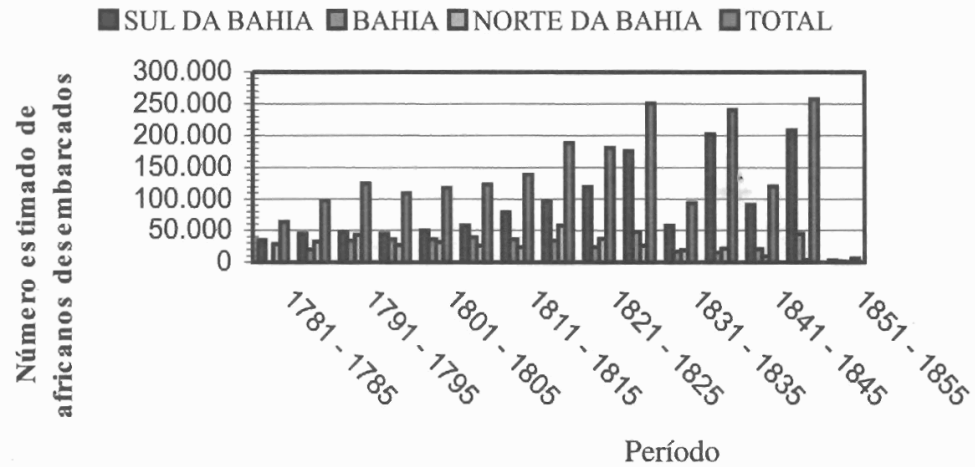

lavouras dessa região tendo em vista que a mão-de-obra utilizada na agricultura era, predominantemente, escrava ${ }^{33}$.

Do total de africanos entrados na Bahia no período 1781-1855, a região Sul da Bahia absorveu $63 \%$ do total, estando relacionado a uma forte expansão agrícola na região, pois neste período houve a expansão das lavouras de café, principalmente ao sul próximo a Caravelas, sendo a Colônia Leopoldina um exemplo, bem como também a introdução da lavoura cacaueira na região de Ilhéus.

Com relação ao trabalho indígena encontramos referência em von Martius, quando descreve a propriedade de Peter Wyell em Ilhéus. Convém salientar uma observação de Von Martius (1981, p. 179) ${ }^{34}$ que descreve no empreendimento alemão a ocorrência de várias formas de trabalho - livre e assalariado, escravo, índios diaristas, em diferentes atividades, como se fosse uma especialização, assim como o cultivo de cana e café, nos anos 10 na Bahia do século XIX.

Todos os relatos mencionam a presença do trabalho escravo e o cultivo de café para a exportação nas terras dos colonos alemães. Não estaria aí uma contradição com os objetivos propostos pelos projetos imigracionistas do século XIX, branqueamento da população, eliminação do trabalho escravo e a diversificação agrícola?

\footnotetext{
${ }^{33}$ Diversos documentos levantados fazem menção aos indígenas sem especificação da sua função dentro das relações de produção das fazendas.

${ }^{34}$ Tivera o Sr. P. Weyll a coragem de estabelecer-se nessa solidão; grandes trechos de mata haviam sido derrubados, queimados e plantados com milho, arroz, cana e café; no vale à margem do Itaípe, que justamente aí forma pequena cascata entre pitorescos grupos de rochedos, estavam os alicerces de um engenho de açúcar, para cuja construção se contratara um contramestre inglês. No cume do morro, que domina toda a sesmaria de uma légua quadrada, pertencente ao nosso hospedeiro, devia ser construida a casa de mora

da. Esses preparativos, executados por dez a doze escravos e por índios, diaristas, de certo modo, só então fizeram compreender ao corajoso colono todo o vulto e todas as dificuldades de sua empresa.
} 
Devemos nos lembrar que o território brasileiro ao início do século XIX não possuía, mesmo nas áreas mais densamente ocupadas e economicamente importantes, vias de circulação terrestre, estradas, e sim apenas caminhos, que quando em melhor situação eram denominados de "carroçáveis», ou seja, aptos à passagem de carroças. Portanto, a colônias européias instaladas, seja na Bahia, seja em outras partes do território, enfrentaram sérios problemas para o escoamento da sua produção. No caso específico da Colônia Leopoldina, a sua principal via de entrada e saída de mercadorias, aí se incluindo os escravos, era feita pelo rio Peruípe, onde o ponto de transbordo das cargas ficava nas proximidades da colônia ${ }^{35}$. Da foz do Peruípe a mercadoria era levada até Caravelas (Porto de Santa Luzia), para então ser enviada ao seu destino final.

Em 1836 foi criada uma companhia de navegação com sede em Salvador, e o privilégio de explorar uma linha regular do porto de Salvador até Caravelas foi dado a João Diogo Sturz . Em 1847 foi fundada a Companhia Bonfim e outra foi criada em 1852, a Companhia Santa Cruz, ampliando a navegação do sul de Caravelas até Maceió. Em 1853 as duas últimas companhias se fundiram, dando origem a Companhia de Navegação Bahiana. A linha costeira percorrida pelos vapores alcançava, ao sul, os portos de Ilhéus, Canavieira, Porto Seguro, Camamu e São José da Colônia Leopoldina (NASCIMENTO, 1986: p. 61-62). O mesmo caminho, ao inverso, era percorrido pelas as mercadorias necessárias para os colonos. Conseqüentemente, $\mathrm{o}$ alto custo do transporte das mercadorias era um fator impeditivo, ou pelo menos, não atrativo para produção de mercadorias para consumo pelo mercado interno. A opção pelo café, já cultivado na região, embora em pequena escala desde o final do século XVIII, permitiu a sobrevivência e enriquecimento da colônia.

A utilização da mão-de-obra escrava está diretamente relacionada à opção pela cafeicultura. Somente com a utilização intensiva de mão-de-obra poderiam as lavouras se tornar lucrativas, e o trabalho escravo estava, já à quase trezentos anos, fortemente entranhado no tecido social da colônia Brasil, sendo desta forma uma opção econômica e social viável, e aceitável. Entretanto, devemos salientar que a forte presença do cultivo de verduras, legumes, frutas variadas e mandioca nos parece caracterizar a produção de alimentos para o auto-abastecimento. Mas quem efetivamente estaria vinculado a esta produção? Podemos inferir que, sendo os escravos renda capitalizada ${ }^{36}$, o seu trabalho estaria reservado à atividade que se inseria no circuito mercantil, a plantation de café. Por outro lado, não sendo todos os colonos proprietários de terras, seriam eles os responsáveis pela produção para o auto-consumo, na situação de homens livres, mas despossuídos de propriedades, caracterizando uma brecha camponesa ${ }^{37}$. A ausência de dados mais detalhados deixa a questão em aberto.

\footnotetext{
${ }^{35}$ Infelizmente, o antigo cais não mais existe, havendo no local, distrito de Helvécia, uma ponte de concreto em substituição a antiga ponte de madeira.

${ }^{36}$ Neste sentido ver MARTINS (1996: p. 15-22).

${ }^{37}$ Sobre a questão da brecha camponesa ver os trabalhos de FRANCO (1997) e SILVA \& LINHARES (1981).
} 
Mas, e quanto ao branqueamento da população, uma importante preocupação das autoridades portuguesas, depois brasileiras, que podemos perceber em diversos documentos, entre eles os do Ministério da Agricultura, Relatórios Provinciais e Fala de Presidentes de Províncias ${ }^{38}$ ? No que tange à área em análise, houve um descompasso entre as intenções e que de fato ocorreu, como percebemos pela leitura dos diversos autores já citados anteriormente. No caso específico da colônia de Leopoldina, há um predomínio do elemento de origem africana, onde este excede em muito aos de origem européia, e Handelmann (1931: p. 457) ${ }^{39}$ nos legou um sucinto relato da situação da colônia.

Sob o ponto de vista do autor, a Colônia de Leopoldina não seria um exemplo adequado de colônia pois, a presença da mão-de-obra escrava desvirtuaria os propósitos da colonização, preferencialmente feita por alemães, pois para ele em lugar do sistema de plantação em fazenda, deve-se, pouco a pouco, adotar o da pequena lavoura; em vez do fazendeiro, o lavrador; em vez do trabalho escravo, o do braço livre (Ibidem: p. 983). Além disso, propunha como solução para incentivar a vinda de imigrantes europeus, mais especificadamente de alemães, dividir o Brasil em três zonas conforme as raças tendo como exemplo os Estados Unidos. Lá, os brancos no norte, os negros no sul e uma zona mista intermediária. Só que no Brasil a posição era invertida (Idem). Nos Relatórios Ministeriais $\mathrm{s}^{40}$ encontramos também referências semelhantes ao se dar preferência para a colonização do litoral por nacionais, onde as febres causavam grande número de mortos entre os imigrantes europeus, reservando para estes terras mais afastadas, no interior, onde o clima seria mais saudável e, portanto, as doenças, febres, menos presentes.

Após 1888, quando da decretação da assinatura de Lei Áurea, em sua maioria, os descendentes dos antigos colonos abandonam a região deixando as terras entregues aos antigos escravos e seus descendentes ${ }^{41}$.

Quando estivemos na localidade ${ }^{42}$, ao entrevistarmos alguns dos moradores, podemos observar que, somente uma minoria possuía noção do real processo de formação

\footnotetext{
${ }^{38}$ Mensagens dos Presidentes das Províncias (1830-1930) e Relatórios Ministeriais (1821-1960).

${ }^{39}$ Fundada em 1818, pelo empresários Busch, Peycke e Freyreiss, à margem do rio Peruhipe, entre Villa Viçosa e Caravellas, que si não tomou grande impulso, todavia se conserva até hoje, e no anno de 1851 comprehendia 43 fazendas de café, com 133 moradores livres e 1.243 escravos. Ella não póde propriamente ser chamada uma colonia agrícola européia, visto incumbirem-se dos trabalhos da lavoura quase exclusivamente os escravos negros; e talvez justamente por esta circunstância é que se tornou possível a sua subsistência, pois em resumo essas faixas de terra costeira ainda são quentes demais para uma vida de lavoura de immigrantes brancos.

${ }^{40}$ Mensagens dos Presidentes das Províncias (1830-1930) e Relatórios Ministeriais (1821-1960).

${ }^{41} \mathrm{Na}$ atualidade a população local é constituída , em sua maioria, por negros e mestiços.

${ }^{42}$ Visitamos a localidade em fevereiro de 2001.
} 
da comunidade ${ }^{43}$. Entre os entrevistados que possuem esta memória devemos citar a senhora Iracema Sluz, cujos avós foram colonos e o senhor José da Paz, que apesar de ter nascido no Espírito Santo na Colônia de Santa Maria, mora em Helvécia desde 1964 e exerce o papel de "guardião da memória da colônia» e do acervo de alguns objetos que pertenceram aos antigos colonos, e que se encontram guardados, de forma inadequada, no sótão da antiga Estação Ferroviária, que pertencia a Estrada de Ferro Bahia-Minas $^{44}$.

Segundo o sr.José da Paz, a presença da Estrada de Ferro Bahia-Minas foi de fundamental importância para a exportação do café dos colonos. Esta estrada, que tinha o porto de Caravelas como seu ponto terminal na Bahia, teve sua construção autorizada por lei no 1.946 de 28 de agosto de 1879 , tendo sido celebrado o contrato entre o governo da província e o engenheiro civil Miguel de Teive e Argollo, em 19 de julho de 1880, para a construção de uma via férrea que partiria da cidade de Caravellas até a divisa da Bahia com Minas Gerais em direção a Philadelphia ${ }^{45}$, estando já em tráfego, em 1884, da Barra de Caravelas aos Aymorés, limite da Província de Minas ${ }^{46}$.

O sr. José da Paz também fez menção ao falecimento do último escravo da antiga colônia com a idade de 123 anos no mês anterior a nossa ida à localidade. Com relação ao ensino na colônia, relatou que nela existiam dois tipos de escolas: a dos brancos e a dos negros (escravos ou não), enquanto as filhas dos colonos eram educadas, em casa, por professores trazidos da Europa, o que parece demonstrar o alto poder aquisitivo de parte dos colonos.

Entretanto, poucos colonos eram donos das fazendas, fato que podemos comprovar pelos documentos levantados, apesar de que após os anos 40 do século XIX várias propriedades foram desmembradas e vendidas, e tal fato parece ter sido iniciado nos anos 30, pois na Proposta de Regulamento da Colônia de Leopoldina ${ }^{47}$, no seu artigo $13^{\circ}$, encontramos uma proposta de venda de terras visando atender algumas das necessidades dos colonos, assim como em documentos referentes aos desentendimentos ocorridos entre colonos e os moradores da Vila Viçosa encontramos reclamações dos moradores sobre as intenções de colonos de venderem parcelas de suas terras a outros colonos, ou entre eles ${ }^{48}$.

\footnotetext{
${ }^{43}$ Boa parte dos moradores da localidade, bem como da sede do município de Nova Viçosa, se referem à localidade como tendo sido um quilombo no período da escravidão.

${ }^{44} \mathrm{O}$ estilo da construção do prédio da antiga estação ferroviária é característico dos países de origem dos imigrantes chamando a atenção dos visitantes.

${ }^{45}$ Relatório Provincial Bahia-1881. p. 56.

${ }^{46}$ Relatório Provincial Bahia-1884. p. 47.

${ }^{47}$ A.N. IA6-154-Fundo Agricultura, Doc. 1. Proposta de Regulamento da Colônia.

${ }^{48}$ A.N. Sesmarias. Cód. BI2-148. 11v. (...) e esta mesma terra que por Mercê se lhe concedêo a querem para negocio de venderem huns a outros por avultados preços e cada vez vem vindo mais, $e$ vão tomando a melhores terras.
} 
Poucos, hoje, são os vestígios da presença dos colonos europeus na região. Os dois cemitérios $^{49}$ que existiam um para colonos e alguns escravos, e outro somente para escravos (Cemitério de São Pedro) foram destruídos, assim como um antigo prefeito ${ }^{50}$ mandou desmanchar a antiga igreja (Nossa Senhora da Piedade) construída pelos escravos, sendo mais recentemente construída uma réplica.

Também a senzala e a antiga cadeia foram destruídas. Um das poucas lembranças que remetem ao período da colônia são as fotos, sem identificação, de uma filha de escravo, de um colono e de seu filho mulato, assim como alguns dos seus objetos, que se encontram expostos no prédio da antiga estação ferroviária. Foi-nos relatado a ocorrência de forte miscigenação entre os colonos europeus e as suas escravas, talvez decorrendo daí a decisão de, ao partirem aos 1888, deixarem as terras para seus descendentes mestiços, ou até mesmo para os antigos escravos. Das antigas famílias de colonos podemos, ainda, encontrar entre outros, descendentes dos Sulz e Morell.

A compra de quase a totalidade da área que compreendia as antigas fazendas, efetuada nos anos 80/90 pela Bahia Sul Celulose destruiu, ou seja apagou, praticamente os vestígios da presença dos colonos europeus na região. Hoje nas antigas áreas coloniais podemos encontrar apenas plantações de eucalipto que se estendem por quilômetros até alcançar a BR 101.

Devemos, neste ponto, nos referenciar a uma outra fazenda, denominada na literatura pertinente como Frankental (EDELWEISS, 1974: p. 597), em referência ao local de origem da maioria dos seus ocupantes. Entretanto, nos documentos depositados no Arquivo Nacional é denominada de Fazenda Jacarandá. De acordo com o Edelweiss, no ano da nossa independência política já existiam, portanto, dois empreendimentos colonizadores no vale do Peruíbe ou Caravelas: Leopoldina e Frankental (idem) e que:

De acordo com o Registro de Estrangeiros, 16 alemães demandaram Caravelas, do Rio de Janeiro, entre 1825 e 1830. destes, ao menos 4 iam com destino a

\footnotetext{
${ }^{49}$ Pelo que podemos presumir a construção do primeiro cemitérios é posterior a 1831 , portanto os sepultamentos deveriam ocorrer em áreas das próprias fazendas a semelhança do descrito por Woortmann in LEIBING \& BERNNINGHOFF-LÜHL, (2001, p. 218) onde podemos ler: (...) nem mesmo um cemitério comum nos primeiros tempos de Brasil. Um cemitério é espaço da ancestralidade compartilhado tanto quanto um «lugar de memória» coletivo. Os primeiros imigrantes foram enterrados em espaços separados que marcam troncos distintos, originados independentemente uns dos outros, $O$ ancestral enterrado ao pé da árvore era herói fundador de "casa tronco» específica, não de uma comunidade.

${ }^{50}$ Não foi nos informado o nome, nem quando o fato ocorreu.

${ }^{51}$ Segundo EDELWEISS, (1974: p. 597)

Em 9 de maio já havia obtido a concessão de uma légua quadrada à sua escolha e, em companhia do negociante João Martinho Flach, de Jorge Antonio von Schäffer, de alguns colonos e de um criado, rumo a Campos. Não tendo, porém, boa impressão das terras pantanosas dessa faixa marítima, continuou a viagem até o rio Caravelas, cujas margens ouvira gabar no Rio de Janeiro. Finalmente, escolheu terras acima da Colônia Leopoldina, à margem esquerda do Peruíbe, que pretendia repartir em lotes individuais a famílias
} 
Frankental, pelo que se deduz claramente do citado Registro, já que foram levados pelo administrador de Schäffer.Entre 1823 e 1830, seguiram, igualmente do Rio de Janeiro, com o mesmo destino: 14 suiços, 2 franceses, 1 italiano e 1 inglês. Infelizmente não sabemos quantos terão tomado o mesmo rumo, saindo da capital Baiana, pois não consta ter havido registro oficial em nossa província. (IDEM)

Mas quem foi von Schäffer? O mínimo que podemos dizer é que se trata de um personagem bastante controvertido, pois dependendo do autor que tomamos como referência tem-se um perfil diferente.

Para Edelweiss, Schäffer era um médico e naturalista que em 1814 passa pelo Rio de Janeiro em um navio russo, retornando em 1818 quando conhece $\mathrm{D}$. Pedro e deve ter impressionado D. Leopoldina pelos seus conhecimentos nas Ciências Naturais (Edelweiss, 1974: p. 596). Após seu retorno da Rússia, onde foi agraciado pelo czar com um título de nobreza, e com as boas recomendações obtidas retorna ao Brasil onde se fixa como colonizador e, após passar pela Bahia, chega ao Rio de Janeiro em $1821^{\text {sI }}$.

de lavradores.Esse médico e major Shäffer, (...), denominou a sua colônia de Frankental, por terem sido originários da região da Francônia tanto ele como os primeiros colonos, que o acompanharam do Rio de Janeiro. Um deles foi provavelmente João Filipe Henning, natural de Wertheim, a quem Schäffer confiou a direção do núcleo. Em 1824, contava ele vinte pessoas.

${ }^{52}$ Os Batalhões Estrangeiros foram criados por lei de 8 de fevereiro de 1823. Para maiores detalhes consultar LEMOS (1993), e Schäffer atuou em nome do governo brasileiro, sob as ordens de José Bonifácio de Andrade e Silva, no aliciamento de mercenários e colonos em vários países ou cidades européias, no início do século XIX.

${ }^{53}$ Diz George Antonio Von Schäffer, natural de Wurtzburgo no Círculo da Francônia n'Allemanha, Doutor em Medicina de Cirurgia e da Arte Obstetrícia e Assessor dos Colégios Imperiais na Rússia, que havendose V.M. Dignado acolher o Supplicante com a maior benignidade na occasion em que elle passou por esta Capital, ha trez annos, e o agazalho que lhe fez S.A.I. e Real, a Archi-Duqueza da Austria e Princeza de Portugal, etc, o animarão a voltar para este paiz, tanto para disputar a utilidade de hum Clima quente para a sua saude, como tãobem para alcançar a Alta Proteção $e$ Favor de V.M. Acostumado o Supplicante, na sua qualidade de Vassalo de S.M. Imperial e Real e Apostólica ao suave Domínio de hum governo Paternal e Patriarcal, elle espera tãobem gozar do mesmo, debaixo do meigo e humano Sceptro de Vossa Magestade, e de conseguir para as Culturas das Sciencias como das artes huma porção de territorio para si e para alguns outros Amigos do Supplicante, na quantidade que V.M. benignamente Houver por bem conceder-lhes na beira do Rio St João ou na de St Pedro. Supplicando porem a V.M. a alta Mercê de lhe permittir, que elle possa pessoalmente escolher entre os territorios livres, e que ainda se não achão dados ou reservados, $\boldsymbol{e}$ que esta data lhe seja feita plena e perpetua propriedade para que elle Supplicante não só possa dedicar-se á Cultura de generos naturaes do Paiz mas até mesmo promover a cultivação de outros objectos Exóticos, e ao mesmo tempo edificar Machanismos para augmento do valor de suas produç̧ões, entre outros, Engenhos de cortar Madeiras e Moinhos de farinha, dos quaes tanto o Real Erário, como o paiz em geral tiraria vantagens, principalmente se aos Amigos e Patrícios do Supplicante for benignamente permittido importarem os seus necessarios Instrumentos e Utencilios livres de todos os direitos. O Supplicante confia. Apud Arquivo Diplomático da Independência. Vol. 4, p. 307. In LEMOS (1993: p. 33-34). 
Todas as referências feitas por Edelweiss são elogiosas a Schäffer, inclusive no tocante ao recrutamento de alemães para emigrarem para o Brasil, seja como mercenários, seja como colonos. Para o autor, o major Schäffer «cai em desgraça» devido a um dos arrebatamentos imperiais, ocorrido após o levante sangrento dos soldados mercenários alemães por ele aliciados, ocorrido em junho de 1828 (Edelweiss, 1974: p. 597), dirigindo-se, então, para a fazendo de sua propriedade situada ao sul da Bahia, aonde veio falecer anos depois.

Para outros autores (ALDINGER, 1923; PORTO, 1934; TSCHUDI, 1976), Schäffer é qualificado como sendo um aventureiro inescrupuloso, mas que desempenhou um importante papel na imigração alemã para as colônias do Rio Grande do Sul (São Leopoldo) e Nova Friburgo, assim como no recrutamento de soldados para comporem os batalhões de estrangeiros ${ }^{52}$.

Provavelmente foi através do cônsul geral da Rússia no Brasil, o barão alemão G. Langsdorff que, em 1821, Schäffer aproximou-se da corte, obtendo de D. João VI terras na forma de sesmaria, as quais cobrou por carta ao soberano quando de sua volta da Europa em 1821 aonde fora tratar de negócios particulares ${ }^{53}$.

Schäffer obteve as terras que reivindicou, e fundou a sua colônia, no sul da Bahia, às margens do rio Jacarandá, um afluente do Peruípe. Ele ainda intermediará a vinda de diversos grupos de colonos e mercenários alemães para o Brasil, mas sai de cena em 1826 provavelmente devido às críticas recebidas tanto por parte dos alemães, quanto por brasileiros devido aos seus métodos de aliciamento ${ }^{54}$. Depois de idas e vindas à Europa retirou-se para a sua fazenda, onde, segundo consta morreu, em 1836, devastado por doenças e pelo álcool (LEMOS, 1993, p. 33).

\section{SOBRE OS CONFLITOS}

Ao longo do período que vai da revolução do Porto até a época da Abdicação, vários são os conflitos que ocorreram cuja fundamentação teve como foco a oposição entre Monarquia ou República, Federalismo ou Centralismo. Se a historiografia coloca os conflitos em termos das classes dominantes dividida entre "partido português»e "partido brasileiro» estes conflitos também alcançaram as classes populares, o povo em geral, onde podemos vê-las dividida entre «portugueses» e «brasileiros».

Se os movimentos decorrentes desta partição entre ser «Português» e ser «Brasileiro» predominam no período mencionado, quando está em construção uma identidade nacional, onde o imigrante português era visto como uma ameaça em potencial ao brasileiro na disputa pelo mercado de trabalho, e no qual o palco principal é representado pelos espaços políticos onde as contendas tendiam assumir um caráter

\footnotetext{
${ }^{54}$ Para um melhor detalhamento dos fatos ver SEYFERTH, Giralda. A Imigração Alemã no Rio de Janeiro. In GOMES (2000: p. 32 et seq). Anno de 1831 - 31.101 alqueires de farinha
} 
preconceituoso e até mesmo racial. Logicamente que tais conflitos tenderiam a se ampliar e a «respingar» em outros imigrantes que não os portugueses.

A maior razão do temor das autoridades constituídas era que os estrangeiros estabelecidos no Brasil pudessem vir agir contra a «Causa do Brasil», sendo os «negócios políticos» motivos de pânico. Para tanto, se deveria ficar alerta contra aqueles que vierem de Portugal (...) ou contra os que viessem do nordeste do país, de regiões como a Bahia e Pernambuco, igualmente reconhecidas pelo apreço aos ideais revolucionários (RIBEIRO, 2002: p. 75).

Vários foram os decretos baixados a partir de 1823 tendo por objetivo restringir, ou pelo menos, controlar e vigiar os imigrantes europeus chegados ao Brasil. Apesar de serem os portugueses o alvo preferido, os decretos eram abrangentes, incluindo, portanto, imigrantes das mais diversas nacionalidades. Devemos, entretanto, nos lembrar que no período em pauta os imigrantes originados dos estados germânicos e das cidades hanseáticas predominam sobre os dos demais países, ou Estados, com exceção dos oriundos de Portugal. Nos anos 30 do século XIX, vários outros decretos, portarias, etc. foram baixados, sempre procurando dificultar e vigiar o ingresso de estrangeiros em terras brasileiras.

É dentro deste quadro que devemos analisar as questões levantadas pela Câmara da Vila Viçosa contra os colonos alemães e suíços. Uma contenda de caráter aparentemente local, paroquial, que se insere num quadro mais amplo, pois os interesses, e os sentimentos envolvidos de ambas as partes reportam a grande questão da constituição da nação brasileira. Os reclamos dos moradores da Vila Viçosa, e as apelações dos colonos não ficam circunscritos ao espaço da Comarca de Porto Seguro. Alcançam a Corte, no Rio de Janeiro, inclusive com a interferência direta do ministro José Bonifácio de Andrade e Silva, e manifestações do Imperador D. Pedro I, como consta em alguns dos documentos levantados.

Mas, afinal, a quais conflitos estamos a nos referir, já que de maneira geral nos diversos relatos referentes à Colônia de Leopoldina não há menção a eles? Cabe aqui uma outra pergunta, tendo em vista o alcance tomado pelas representações feitas de ambas as partes. Estaria no fundo da questão do «esquecimento» dos conflitos uma manifestação de insatisfação com a política imigratória adotada desde o início do século XIX? Lembremo-nos que «história» da Colônia Leopoldina é sempre mencionada de forma vaga, e muitas vezes o empreendimento é reportado com um exemplo de «insucesso», seja porque o número de «brancos europeus» é insignificante, seja pela utilização da mão-de-obra escrava. Talvez esteja aí, nos conflitos ocorridos entre 1823 e 1832, a «chave» para a interpretação do «esquecimento», ou «negação da memória» da Colônia, estando a pista nos documentos disponibilizados.

Mas vamos aos fatos.

A instalação da Colônia Leopoldina deu-se em uma região caracterizada pela apatia econômica expressa na baixa rentabilidade das lavouras de subsistência, apesar da 
presença de solos propícios à agricultura, e pelo «vazio demográfico» decorrente tanto da postura assumida pelo governo metropolitano ao longo do século XVIII, que ao permitir a ampliação das áreas indígenas, os «terríveis botocudos» da historiografia tradicional e dos relatos dos viajantes, dificulta, ou até mesmo inviabiliza em grande parte desta região, a instalação de povoações de caráter permanente por portugueses. Esta política começa a ser mudada com a chegada da corte portuguesa à colônia.

A presença de colonos alemães, seja em Leopoldina, seja em Helvécia, que posteriormente passa a integrar a área da colônia, promoveu uma transformação radical nas relações de produção, cujos frutos foram a lucros advindos da venda dos seus produ$\operatorname{tos}^{55}$. De acordo com o doc. 6, Série Agricultura, IA6 159 do Arquivo Nacional, que trata do recolhimento dos dízimos sobre a produção da Villa Viçosa - 20 de fevereiro de 1832: Anno de 1827/1828 - alqueires de farinha d'água 6.332. Anno de 182920.790 alqueires vendido ao preço, onde se destaca o café.(Tabela 1)

\section{Tabela 1 - Transporte para fora da Villa Viçosa do café dos colonos alemães}

\begin{tabular}{lrrrrrrr} 
Fazendeiros & \multicolumn{7}{c}{ Arrobas de Café por anno } \\
\cline { 2 - 8 } & 1826 & 1827 & 1828 & 1829 & 1830 & 1831 & 1832 \\
\cline { 2 - 8 } Flach & - & - & 105 & 2.378 & - & 1.576 & 2.325 \\
Pedro Peck & - & - & 303 & 2.30 & 1.931 & 1.815 & 855 \\
Fazenda Pombal & - & - & 843 & 1.339 & 2.495 & 1.175 & 1.078 \\
Abraão Langhans & - & - & 110 & 217 & 601 & 344 & - \\
LuizAlbenoers & - & - & 68 & 387 & 235 & $360+204$ & - \\
Augusto Confformart(?) & - & - & 300 & 760 & 500 & 800 & 709 \\
Maulas Conandier & - & - & - & & - & 365 & 702 \\
Roberto(?) & - & - & 148 & 1830 & - & - & - \\
Alexandre(?) & - & - & - & 299 & - & - & - \\
João Luiz Wasserfall & - & - & 200 & -233 & -345 & - & - \\
João Jorge Felipe & 52 & - & - & 97 & 92 & 75 & $44+99$ \\
João Felipe H. & 150 & - & 208 & 289 & 443 & - & - \\
Joana von Froir(?) & 62 & - & 100 & 167 & 251 & - & 200 \\
João P. Hanteffal(?) & 463 & - & 196 & 661 & 369 & - & - \\
Joaquim Petersen(?) & - & - & - & 170 & 220 & 343 & 195 \\
Cel. Jorge A. Schäffer & - & - & - & - & - & - & 876 \\
\hline
\end{tabular}

Fonte: elaborada a partir dos dados contidos em documentos encontrados no Arquivo Nacional ${ }^{56}$.

\footnotetext{
${ }^{55}$ De acordo com o doc. 6 , Série Agricultura, IA ${ }^{6} 159$ do Arquivo Nacional, que Trata do recolhimento dos dízimos sobre a produção da Villa Viçosa - 20 de fevereiro de 1832:

Anno de 1827/1828 - alqueires de farinha d'água 6.332

Anno de 1829 - 20.790 alqueires vendido ao preço

Anno de 1831 - 31.101 alqueires de farinha

${ }^{56}$ A.N. Série Agricultura, IA6-159, doc. 6.
} 
Mas não apenas café produzia os colonos. Verduras, legumes, frutas variadas e mandioca eram produzidas em suas fazendas. Por outro lado, as lavouras dos habitantes da Vila restringiam-se a da mandioca, e mesmo assim a produção não atendia as necessidades locais.

As questões apresentadas pelos moradores da Vila Viçosa a Câmara Municipal, e que alcançam a Corte no Rio de Janeiro, demonstram de forma inequívoca que não se tratava de uma «querela paroquial», estando em jogo interesses de maior vulto. Os moradores da vila reivindicavam para si as terras da colônia, e os argumentos empregados vão desde da apropriação indevida das melhores terras pelos colonos até insinuações sobre a sua lealdade para com a Coroa, sugerindo a formação de complôs de caráter republicano, como podemos ler em vários trechos dos documentos relativos à colônia $^{57}$. Em vários documentos ${ }^{58}$ os colonos buscam demonstrar sua lealdade para com a Coroa, e em vários outros de igual teor, temos exemplo das insinuações supra-referidas.

O principal argumento utilizado pelos moradores da Vila é de que a Colônia estaria instalada em terras pertencentes à Comarca, e que os colonos, assim, não seriam os seus legítimos proprietários, podendo as terras, se utilizarmos um termo atual, serem desapropriadas. Em verdade, as terras doadas em sesmarias aos colonos pertenciam à Coroa, sendo, portanto, passíveis de serem doadas, como consta em peças da defesa utilizada pelos colonos, incluídas nos documentos que levantamos, e que são cópias dos Autos de Demarcação e Marcação das Terras, bem como dos Autos de Posse

\begin{abstract}
${ }^{57}$ A.N. IA6-154-Fundo Agricultura, Doc. 1. Encontramos (...) que no regimento da colônia e suas reuniões não são tratados de assuntos republicanos como poder ser visto pela cópia do referido regulamento enviado (...) estando dispostos a mudar qualquer artigo que esteja contra as leis do Império. Ass. Augusto Tavel.

${ }^{58}$ Termo de Justificativa dos Colonos Alemães - 14 de fevereiro de 1832. O Cônsul Pedro Peyck e os mais colonos allemães residentes na Colônia Leopoldina districto desta villa que lhes precizão justificar por este Juizo, citado o Procurador da Comarca por que vem jurar destes abaixo declarados: Item Just. que os justificantes são moradores no sobredito lugar aonde tem vivido pacificamente a honze para doze annos sem obstáculos algú e sem a mínima oposição de pessoa alguma até o presente Item Just. desde o princípio das suas chegadas sempre se tem mostrado obedientes as Authoridades, assim civeis, Ecleziasticas ou Militares tanto desta Villa como ainda das circunvizinhas Item Just. os Justificantes que vivem com exclarecido procedimento afastado de todos os partidos que desegenerão os homens probos e honrados não só entre elles, os abitantes deste Pais, como também dando a seus escravos, famílias brilhantes exemplos de obediência para com todos os indevidos (sic).Item Just. que emitido o decurço dos annoz acima expedidoz não tem corrido em cazo algú crime, que onde se comprova facilmente a reverencia e obediência inteira que tem as Leis deste Império, e profunda submição as Authoridades instituídas.
\end{abstract}

A.N. Série Agricultura, IA6- 159, doc. 7. Seguem-se testemunhos de: Jorge de Almeida e Silva Branco, Francisco Moreira Branco, Manoel dos reis e Almeida Branco, Jorge Corrêa de Mattos Branco, Jorge Francisco de Viveiro Branco que confirmam, integralmente os quatro itens. 
emitidos conforme a legislação vigente ${ }^{59}$. A documentação deixa claro que, ao receberem as Sesmarias em doação os colonos solicitaram a demarcação e marcação das mesmas, no que foram atendidos e que todo o processo seguiu fielmente as instruções normativas.

Uma outra argumentação utilizada pelos moradores diz respeito à escassez de terras para cultivo e para obtenção de madeiras para lenha e para a construção de suas casas, visto as grandes áreas ocupadas pelos colonos. Esta tambêm é improcedente, pois a maioria das terras da vila encontrava-se inculta, e ocupadas por matas, sendo que a baixa produtividade das suas lavouras era devida, segundo os colonos, a «apatia» dos moradores da vila que não eram afeitos ao trabalho e, portanto, não a escassez de terras cultiváveis. Também mencionam a seu favor que quando da sua chegada as suas terras estavam cobertas de matas virgens, derrubadas pelos colonos para poderem dar início as suas lavouras ${ }^{60}$.

Um fato que chama a atenção no tocante os conflitos entre os moradores da vila e os colonos alemães é que em nenhum dos documentos consta qualquer tipo de movimento contra o Coronel, ou Major, Georg Anton Schäffer, também proprietário de uma sesmaria doada pela Coroa, nas vizinhanças da colônia Leopoldina, por parte dos moradores da Vila Viçosa. Ao contrário, as acusações que encontramos partem dos colonos alemães e suíços contra ele.

Cabe aqui uma pergunta. Estaria Schäffer por trás do movimento empreendido contra os colonos de Leopoldina? Com quais objetivos? São perguntas que não temos como responder pois nos faltam maiores dados, mas presumimos que sim, tendo em vista ser ele um personagem de personalidade discutível, como já mencionamos, e pela a amplitude assumida pelo conflito, que inclusive envolveu agressões físicas aos colo-

\footnotetext{
${ }^{59}$ Alvará de 25 de janeiro de 1809. Sobre a confirmação de Sesmarias, forma de nomeação dos Juizes, e seus salários. Quarto livro das Ordenações Filipinas, p. 1028.

${ }^{60}$ A. N. Sesmarias - CÓD.: BI2-148.

${ }^{61}($...) Depois que chegou um colono chamado Coronel Schaffer - apareceram as dificuldades

- (...) fez intrigas com as autoridades da Vila aproveitando das férias (da Câmara?), que as vítimas são eles os colonos. São forçados a dizer que a 15 de dezembro de 1831 uma parte dos plantadores $e$ (da) colônia foram chamados para a plantação do Sr. Roeder (?) por um alarme. Ao chegar lá os colonos foram informados dá existência de uma rixa, viram através do estrago dos porcos, sobre as plantações da Jacarandá pertencente aos Srs. Schaffer e, que os negros da dita plantação Jacarandá teriam maltratado o Sr. Roeder com espingardas e o arrastado a força até a Jacarandá com violência, e foi batido por paus até sangrar, com a intençẩo de o manter ao tronco. Informamos que até a presente data (ano) negro de parte nenhuma cometeu tal temeridade, muito menos contra brancos. Após a chegada do Sr. Coronel ou Major Schaffer na colônia (dele) os negros tem tido uma obstinada insubordinação, exemplo bem funesto para os negros das outras plantações. Os mesmos negros da Jacarandá imprudentemente armados de espingardas se dirigiram a plantação de Leopoldina para convidar os negros da dita plantação a se juntarem a eles contra os brancos. Isto merece uma reflexão por fazer sentir a conseqüência destes fatos para a segurança da colônia e do país em geral ée aplicável. Tradução do original em francês. A.N.IA6-154-Fundo Agricultura, doc. 1.
} 
nos de Leopoldina por parte de escravos da sua fazenda, a Jacarandá61 .

A intenção por parte da Câmara em revogar a concessão de terras feitas aos colonos por D. João VI, pode ser vista na Ata da Sessão da Câmara de Vila Viçosa de 06 de fevereiro de 1832 que se refere a Sessão de 31 de janeiro de 1832 na qual havia sido acordado que os Colonos Allemães situados no rio acima desta Villa na Colônia de Leopoldina deveriam apresentar nesta seção suas sesmarias ${ }^{62}$. Entretanto, João Martinho Flack apresenta seu título de posse da sua fazenda, conhecida usualmente por Helvécia ${ }^{63}$, que lhe teria sido concedida por D. Pedro I. A Câmara não reconheceu da validade da posse das terras por parte de Flack, Pedro Paycke, Felipe Hulguemin e Abraão Langhans, que apesar de apresentarem os autos de medição e demarcação não apresentaram o Alvará, o Decreto, ou Carta Régia da concessão da meia légua de terras. Como consequiência, a Câmara deliberou por os proibir de vender, arrendar, explorar madeiras, cultivar nas suas terras, concedendo o prazo de um ano para a apresentação dos documentos supracitados, sob pena deles perderem suas terras para habitantes e Nacionaez desta Villa estabelecer-se com suas culturas pela falta de terras, que há os ditoz Allemães para baixo não podião fazer por estez se chamassem a posse das referidas terras por cuja razão determinão os ditos vereadores, que visto $(\ldots)^{64}$.

É interessante notar que a contestação à posse das sesmarias por parte da Câmara da Vila Viçosa inicia-se em 1823 quando João Martinho Flack solicita que o Juiz Ordinário da Vila Viçosa proceda à medição e demarcação competente ${ }^{65}$ de suas terras, pois na ausência destas estaria impedido de cultivá-las e tendo, portanto, grandes prejuízos tanto em perda de tempo como em face de quinze escravos que já nove mezes comprou e mandou para Caravellas para o fim de cultivar esta sesmaria $(. . .)^{66}$. No documento $08^{67}$ o autor diz que apesar da Provisão de 21 de janeiro de 1823 esta não surtiu efeito, referindo-se a Paulino da Costa do Nascimento e Giraldo José da Costa, Cabeças do Povo, que não fizeram as devidas diligências necessárias para demarcação e marcassão das terras. Em outros documentos de igual teor mostram que o autor sente-se prejudicado pelos atrasos.

No documento $10^{68}$, datado de 21 de fevereiro de 1824, assinado por José Antonio d'Andrade Pinto, José da Silva Lisboa e D. Antonio (ilegível), D. Pedro ordena ao Ouvidor da Comarca de Porto Seguro que proceda às devidas averiguações, e mande seu parecer em carta fechada. Nos documentos seguintes vemos que as determinações do imperador

\footnotetext{
${ }^{62}$ A.N. IA6-154-Fundo Agricultura, Doc. $3 b$.

${ }^{63}$ Idem.

${ }^{64}$ Idem.

${ }^{65}$ A. N. Sesmarias - CÓD.: BI2-146. 06 e 06v.

${ }^{66}$ Idem.

${ }^{67}$ A. N. Sesmarias - CÓD.: BI2-146.

${ }^{68}$ Idem.

${ }^{69}$ Ibidem. Doc 16 ao 29v.
} 
foram cumpridas, e ao final a medição e demarcação das terras foram feitas ${ }^{69}$, inclusive com mapa, bem como foi emitido o Auto de Posse ${ }^{70}$. Entretanto, nos documentos que se seguem $^{71}$ vemos que apesar de os trâmites legais terem sido cumpridos, a Câmara da Vila Viçosa através de Paulino da Costa do Nascimento e Geraldo Jorge da Costa (ou seria Giraldo José da Costa?) continuam a contestar a posse da sesmaria por parte dos alemães ${ }^{72}$.

Como consequiência destes desentendimentos entre os moradores da vila e os colonos europeus, temos a produção de uma memória por parte do Cônsul Tavel, assim como de uma Proposta de Regulamento para a Colônia de Leopoldina, bem como um documento assinado por Nicolau Pereira de Campos Vergueiro ${ }^{73}$ dirigido ao Presidente da Bahia, em favor dos colonos.

Entretanto, a Câmara da Vila Viçosa continua a insistir na revogação da concessão das terras aos colonos em 1832, como nos mostra o documento produzido em 1831 pelo Secretário da mesma Câmara ${ }^{74}$.

Podemos, portanto, depreender dos vários documentos consultados que os conflitos

\footnotetext{
${ }^{70}$ Ibidem. Doc. 35
}

${ }^{71}$ Doc. 40 a $46 \mathrm{v}$.

${ }^{72}$ Nos documentos das Sesmarias - CÓD.: BI2-146, datas limites 1824-1828, tendo como requerentes a Câmara da Vila Viçosa versus Joaquim Martinho Flack, Carlos Luiz Borrel, Felipe Hugermin, Pedro Henrique Béguin, Abram Langhaens e David Pache, temos uma repetição dos fatos acima descritos, não cabendo, portanto reproduzi-los.

${ }^{73}$ A.N. IA6-154-Fundo Agricultura, Doc. 4, estando junto com o 3b. Ao Presidente da BahiaEm 6 de setembro de 1832Tenho a honra de passar ás mãos de V. Exa as inclusas cópias das notas preparadas pelo Cônsul das Cidades Hanseáticas, e pelo da Suissa, acompanhado de uma memória dos seus concidadãoes, que em grande parte formam a Colônia Leopoldina, na comarca de Porto Seguro, e tomo a liberdade de chamar a attenção de V.Exa para todos aquelles Documentos, na fundada esperança de que V. Exa, tendo em consideração o estado prospero em que consta achar-se a dita Colônia, e o quanto convem favorecer no Brasil semelhantes estabelecimentos se apressará à definir aos requerentes, como fôr de justiça, providenciando igualmente sobre o que elles representão relativamente à Câmara Municipal de Villa Viçosa. Deus Guarde à V. Exa. Palácio do Governo.

${ }^{74}$ A.N. IA6-154-Fundo Agricultura, Doc. 3b. Joaquim Affonso Cardoso Secretário da Câmara Municipal desta Villa Viçosa deste termo. Certifico que revendo o Arquivo da mesma Câmara encontrei o Auto destas terras e de marcação que pede o suplicante:

Auto de Medição e de Marcassão de uma légua de terras no lugar da nova Povoação Leopoldina da parte Sul do rio geral, nesta Villa denominado Peruípe no lugar chamado Pombal, concedidas por graça de Sua Magestade aos colonos Suissos Carlos Luiz Borrel, Felippe Huguemin e Pedro Henrique Béguin - escrivão Antonio Pereira dos remédios - Anno de Nascimento de Nosso Senhor Jesus Christo de mil oitocentos e vinte hum aos vinte dias do mês de Dezembro do dito anno, e primeiro da Constituição Nacional da Monarchia nesta Villa Viçosa da Comarca de Porto Seguro, e Cartório de mim Escrivão ao diante nomeado ahi por parte dos Colonos Suissos Carlos Luiz Borrel, Felipe H. e Pedro Henrique B. estabelecidos na nova Povoação denominada Leopoldina no Rio acima desta mesma Villa chamado Peruípe no termo della no lugar chamado Pombal da parte do Sul do mesmo Rio por parte dos mesmos me foi apresentado huma sua Petição Despachada pello Doutor Antonio Joaquim 
entre os naturais de Vila Viçosa e os colonos estrangeiros se prolongaram por mais de uma década, têm sido acirrados no período da presença do coronel Schäffer, inclusive com mortes ${ }^{75} \mathrm{e}$ ameaça de rebelião dos escravos. Estranhamente não encontramos mais nenhum documento pertinente aos conflitos com data posterior a 1832. Sabendo-se que o dito coronel já se encontrava adoentado, e tendo falecido segundo consta em 1836, estaria ele realmente envolvido nos conflitos, ou não? Somente mais pesquisas em busca de novos documentos poderão esclarecer os fatos ${ }^{76}$.

Um outro fator que parece ter sido relevante para o término dos conflitos entre moradores e colonos, pode ter sido a cessação dos problemas de ordem interna do Império, seja a pacificação das províncias rebeldes, na qual a Bahia se incluía, seja a Abdicação do Imperador e o seu retorno a Portugal. O que temos de concreto é que, aparentemente os conflitos cessaram e a colônia prosperou de tal sorte que em 1847 apesar de ainda se denominar Colônia Leopoldina, a maioria das suas terras já haviam sido vendidas para os antigos colonos, e outros mais que chegaram, e posteriormente foi criada a Sociedade do Porto de São José, formada pelos fazendeiros de café, principal produto das suas terras. Daí as referências de autores como as citações feitas por Amaral (1923: nota de rodapé 359), Palazzolo (1973: nota 358) e Fouquet (1974: p. nota 357), além de Costa (1999: p. 308) onde se lê:

Até meados do século [XIX], a única colonia que parece ter prosperado foi a colonia de Leopoldina, estabelecida em 1818 no termo de Caravelas. Era composta de suiços e alemães. Em 1848, exportava setenta mil arrobas de café. Contavam-se no núcleo 130 pessoas livres, entre estrangeiros e nacionais, alguns

Teixeira de Oliveira, Provedor Geral e Corregedor desta Comarca de Porto Seguro para bem de se lhe medir e demarcar meia légoa de Terras em quadro no lugar chamado Pombal em cujo lugar já se achavão situados cafezais dados aos ditos colonos com suas culturas para os treis suplicantes cujas terras lhes foi dada, e concedidas por Graça e Mercê de Sua Magestade como primeiros povoadores daquelle lugar e porquê já se achavão cituados os Herióz confrontantes com quem partião as ditas terras como constava se via das Certidões que das mesmas citações exaradas ao pé da mesma Petição expedião e segundo que na conformidade do mesmo Despacho das citações constasse para afim de se proceder na dita medição e demarcação no mesmo dia consignado e designado pelo dito Ministro, recebendo na dita Petição com a fé das Citações, e por não contar duvida ou embargo algum acatarei com o presente termo de autuação para se tratar do mais necessario cujo eu aqui no adiante se segue debaixo desta mesma Autuação que eu Antonio Pereira dos Remédios Escrivão aqui escrevi. Seguemse os Autos de Medição e Demarcação das Terras conclusos em 26 de dezembro de 1831.

${ }^{75}$ A. N. Sesmarias- CÓD.: BI2-148. Relatório do enviado da Coroa para averiguação dos fatos.

${ }^{76}$ Cabe assinalar que muitos dos documentos e livros de ata da Câmara de Vila Viçosa foram queimados, numa fogueira, por um ex-prefeito do município nos anos 90 do século $\mathrm{XX}$, segundo nos foi informado pela Dra. Jean, médica, pesquisadora e moradora do município. Talvez este fato em muito dificulte um aprofundamento da pesquisa, pois parte da documentação pertinente ao tema tornou-se cinza, literalmente. 
indios e mais de mil escravos.

Portanto, somos forçados a discordar de Braudel, que nos deixou o seguinte artigo quando de sua presença no Brasil nos anos 30 do século XX.

Entretanto, desde o início do século XIX, tentativas foram feitas para estabelecer colônias estrangeiras, principalmente germânicas. Fracassaram todas. Otto Quelle, num artigo da «Ibero-Amerikanisches Archiv» levantou uma relação dessas tentativas, cuja tradução figura no 39 da Revista do Instituto Histórico e Geográphico da Bahia. Leopoldina, fundada em 1818 a margem do rio Peruíbe, com colonos suissos, parece ter sido o único centro a prosperar; entretanto, como observou já há muito tempo Francisco Vicente Vianna deve-se o seu surto de progresso á mão de obra servil, o que equivale dizer que o emprehendimento, do typo bahiano, foi na realidade europeu. Mas como explicar o desapparecimento desses enxertos estrangeiros, tal como aconteceu com o grupo de soldados irlandezes, estabelecidos perto de Ilhéus em 1823 ? (..) Mas não haverá, entretanto, para esse fracasso geral, uma explicação de conjunto para a qual não se attente? (...) Assim, não será digno de registro o facto de, na grande zona em que há de se installar em fins do século XIX o reino do cacau, se originarem todos os seus elementos, capitaes e homens, do Brasil baiano: os capitaes das famílias commerciantes da cidade, os homens do reservatório dos sertões que vão do São Francisco até Sergipe e mesmo além.(BRAUDEL. 1937)

É nosso entendimento, enfim, que a evolução da Colônia de Leopoldina não resultou em fracasso e sim numa mudança de rumo tomada em direção a sua inserção no setor agro-exportador, setor este prevalecente na economia brasileira desde os primórdios de sua elaboração até a segunda metade do século XX, quando um processo de industrialização restrito e dependente aflora. Por outro lado, concordamos com as afirmativas de Braudel, no tocante a ter se dado no espaço sul da Bahia a emersão dos elementos mais significativos da economia baiana no final do século XIX. Não estaria por detrás destes elementos a presença invisível dos colonos alemães e suíços e de seus descendentes? Novas perguntas, novas questões a serem respondidas.

\section{O RESGATE DE UM ESQUECIMENTO - A COLÔNIA DE LEOPOLDINA}

Resumo: O presente trabalho trata, essencialmente, de recuperar alguns aspectos da imigração e instalação de colônias alemãs na região sul da Bahia no alvorecer do século XIX, buscando o resgate de um esquecimento - A Colônia de Leopoldina.

Palavras-chaves: Imigração, Bahia, Alemães, Século XIX, Colônia Leopoldina

\section{RESCUE OF A FORGETFULNESS - THE LEOPOLDINA'S COLONY}

Summary: The present work deals, essentially, with some aspects of the immigration and installation of German colonies in the south area of Bahia in dawning of the century XIX, 
looking for the rescue of a forgetfulness - the Leopoldina's Colony.

Key-words: Immigration, Bahia, German, XIX Century, Leopoldinas's Colony

\section{BIBLIOGRAFIA}

ALDINGER, P. (1923). Deustche Mitarbeit in Brasilien, Curitiba: T. Locher.

AMARAL, Bráz do. (1923). História da Bahia do Império à República. Bahia: Imp. Official do Estado.

CARNEIRO, Fernando. Imigração e colonização. (1950). Rio de Janeiro: Universidade do Brasil.

COSTA, Emília Viotti da. (1999). Da Monarquia à República: momentos decisivos. $7^{\star}$ ed. São Paulo: Fundação Editora da UNESP.

FRANCO, Sylvia de Carvalho. (1997). Homens livres na ordem escravocrata. $4^{\mathrm{a}}$ ed. São Paulo: Fundação da Editora da UNESP.

FREYRE, Gilberto (Org.).(1974). III Colóquio de Estudos Teutos-Brasileiros Recife: Ed. Universitária/UFPe.

GOMES, Ângela de Castro (org.).(2000). Histórias de imigrantes e de imigração no Rio de Janeiro. Rio de Janeiro: 7 Letras.

LEIBING, Annete e BERNNINGHOFF-LÜHL, Sibylle (org.). (2001). Devorando o tempo: Brasil, o país sem memória. São Paulo: Mandarim.

LEMOS, Juvêncio Saldanha. (1993). Os mercenários do Imperador: a primeira corrente imigratória alemã no Brasil, 1824 - 1830. Porto Alegre: Palmerinca.

LYRA, Itaberaba Sulz. Anjo bom, anjo mau. (1997). Salvador: BDA.

MARTINS, José de Souza. O Cativeiro da Terra. (1996). $6^{a}$ ed. São Paulo: Editora HUCITEC.

NASCIMENTO, Iolanda Maria do. O comércio de cabotagem e o tráfico interprovincial de escravos em Salvador (1850-1880).(1986). Dissertação de Mestrado. Niterói, RJ: PPGH/UFF.

PALAZZOLO, Frei Jacinto. (1973). Nas selvas dos vales do Mucuri e do Rio Doce. $3^{\mathrm{a}}$ ed. ver. Brasiliana, vol. 27. São Paulo: Companhia Editora Nacional.

PORTO, Aurélio. (1934). O trabalho alemão no Rio Grande do Sul. Porto Alegre: Estabelecimento Gráfico Santa Terezinha.

RIBEIRO, Gladys Sabina. (2002). A liberdade em construção: identidade nacional e conflitos antilusitanos no primeiro reinado. Rio de Janeiro: Relume Dumará: FAPERJ.

SILVA, Francisco Carlos Teixeira da e LINHARES, M. Yeda. ( 1981).História da agricultura brasileira. São Paulo: Brasiliense.

SPIX, Johann Baptist von. (1981). Viagem pelo Brasil: 1817-1820; Spix e Martius. $4^{\mathrm{a}}$ ed. São Paulo: Ed. da Universidade de São Paulo. 
TSCHUDI, J. J. von. (1976). Viagens às Províncias do Rio de Janeiro e São Paulo. Biblioteca Histórica Paulista. São Paulo: Livraria Martins Editora.

TÜTKEN, Silza Fraga da Costa. (1986). Comércio e comerciantes alemães na Bahia. 1870-1914. São Paulo, 1986. Tese de Doutorado. São Paulo: FFLCH/USP.

\section{FONTES:}

Arquivo Nacional (A.N.)

- Fundos:

Série Agricultura - Terras Públicas e Colonização

Sesmarias Bahia

\section{- Publicações do Arquivo Nacional}

Registro de Estrangeiros nas Capitanias: 1777-1819. Rio de Janeiro: Arquivo Na-cional:, Ministério da Justiça e Negócios Interiores, 1963.

Registro de Estrangeiros - 1808-1822. Rio de Janeiro: Arquivo Nacional:, Ministério da Justiça e Negócios Interiores, 1960.

Registro de Estrangeiros - 1823-1830. Rio de Janeiro: Arquivo Nacional:, Ministério da Justiça e Negócios Interiores, 1961.

Registro de Estrangeiros - 1831-1839. Rio de Janeiro: Arquivo Nacional:, Ministério da Justiça e Negócios Interiores, 1962.

Catálogo das cartas régias, provisões, alvarás, avisos, portarias, etc., expedidas ao governador e mais tarde Vice-Rei do Rio de Janeiro de 1662 a 1821.

Coleção das Decisões do Governo do Império do Brasil de 1827. Rio de Janeiro: Typografia Nacional, 1878.

Coleção das Leis do Brasil de 1820. Decretos, Cartas Régias e Alvarás de 1820. Rio de Janeiro: Imprensa Nacional, 1889.

Coleção das Leis do Império do Brasil de 1823 (Leis da Assembléia Constituinte e Legislativa). Rio de Janeiro: Imprensa Nacional, 1887.

Coleção das Leis do Império do Brasil de 1828. Rio de Janeiro: Typographia Nacional, 1878.

\section{Outras Fontes:}

- Arquivo do Instituto Hans Staden. São Paulo

- Revista do Instituto Histórico e Geográfico Brasileiro

FOUQUET, C. O imigrante alemão e seus descendentes no Brasil 1808 - 1824 1874. (1974). São Paulo: Instituto Hans Staden. 
HANDELMANN, Henrique. História do Brasil. [1 ${ }^{\text {a }}$ ed. 1859]. (1931). Trad. pelo Instituto Histórico e Geográfico Brasileiro. Rio de Janeiro: Nacional.

ROUVE, Agenor de. Política Econômica de D. João VI. (1928).In Revista do Instituto Histórico e Geográfico Brasileiro, Tomo Especial, Congresso Internacional de História da América - 1922, Vol. VI. Rio de Janeiro: Imprensa Nacional.

\section{Internet:}

- http://wwwcrl.uchicago.edu/info/brazil/pindex.htm. Projeto de Imagens de Publicações Oficiais Brasileiras. (Mudou para http://www.crl.edu/content/pindex.htm)

- Mensagens dos Presidentes das Províncias (1830-1930)

- Relatórios Ministeriais (1821-1960)

- http://www.uc.pt/ihti/proj/filipinas/ORDENACOES.HTM

Ordenações Filipinas on-line 